\title{
HUBUNGAN DIABETES MELLITUS PADA KLIEN YANG MENGGUNAKAN INSULIN DENGAN GEJALA OSTEOARTHRITIS DI RSUD DR. H. ABDUL MOELOEK PROVINSI LAMPUNG
}

\author{
Andoko ${ }^{1}$, Dessy Hermawan ${ }^{2}$, Rika Yulendasari ${ }^{3}$
}

${ }^{1}$ Dosen Program Studi Ilmu Keperawatan Universitas Malahayati Email: andoko@gmail.com

${ }^{2}$ Dosen Program Studi IImu Keperawatan Universitas Malahayati

Email: hermawan.dessy@gmail.com

${ }^{3}$ Dosen Program Studi Ilmu Keperawatan Universitas Malahayati

Email: rikajeng@yahoo.com

\section{ABSTRACT : DIABETES MELLITUS RELATIONSHIP IN CLIENTS USING INSULIN WITH SYMPTOMS OSTEOARTHRITIS IN DR. H. ABDUL MOELOEK PROVINSI LAMPUNG \\ YEAR 2018}

Background : Based on data from Lampung Provincial Health Office, pravelensi of insulin-dependent diabetes mellitus in Lampung Province in 2015 amounted to 123 clients who were hospitalized, while client with outpatient as many 40 people. In 2016, the number of outpatient visits in patients with diabetes mellitus amounted to 28 people, while in hospitalization increased to 185 clients (Provincial Health Office of Lampung, 2016).

Purpose : The purpose of this study is to know the relationship of diabetes mellitus in clients who use insulin with symptoms of osteoarthritis in RSUD Dr. H. Abdul Moeloek Lampung Province Year 2018.

Method : This type of research is quantitative (non-experimental). The design of this study was an analytical survey using the cross sectional approach, the population of all diabetic patients using insulin in $\mathrm{Dr}$. H. Abdul Moeloek Province 2018 as many as 214 people and got the number of samples of 59 respondents, the sampling technique in this study is simple random sampling, statistical test using chi-square test.

Result : The result of chi square statistic test obtained $P$-Value $<a(0,02<0,05)$ then $\mathrm{HO}$ is rejected. So it can be concluded there is a relationship of diabetes mellitus in patients who use insulin with the incidence oeteoartritis in RSUD Dr. H. Abdul Moeloek Lampung Province Year 2018 with Odds Ratio $(O R)=2.037$.

Conclusion : Suggestions can be used as an information and input material to improve the patient's knowledge of using insulin, which can affect weight gain, and affect lower extremity and muscle function, thus causing symptoms of osteoarthritis.

Keywords: Diabetes Mellitus, Insulin, Osteoarthritis

INTISARI : HUBUNGAN DIABETES MELLITUS PADA KLIEN YANG MENGGUNAKAN INSULIN DENGAN GEJALA OSTEOARTHRITIS DI RSUD DR. H. ABDUL MOELOEK PROVINSI LAMPUNG

Pendahuluan : Berdasarkan data dari Dinas Kesehatan Provinsi Lampung, pravelensi diabetes mellitus tergantung insulin di Provinsi Lampung pada tahun 2015 sebesar 123 klien yang mengalami rawat inap, sedangkan klien dengan rawat jalan sebanyak 40 orang. Pada tahun 2016, jumlah kunjungan rawat jalan 
pada pasien diabetes mellitus berjumlah 28 orang, sedangkan pada rawat inap mengalami peningkatan menjadi 185 klien (Dinkes Provinsi Lampung, 2016).

Tujuan : Tujuan penelitian ini adalah untuk diketahui hubungan diabetes mellitus pada klien yang menggunakan insulin dengan gejala osteoarthritis di RSUD Dr. H. Abdul Moeloek Provinsi Lampung Tahun 2018.

Metode : Jenis penelitian ini adalah kuantitatif (non-eksperimen). Rancangan penelitian ini adalah survey analitik dengan menggunakan pendekatan cross sectional, Populasi seluruh pasien diabetes yang menggunakan insulin di RSUD Dr. H. Abdul Moeloek Provinsi tahun 2018 sebanyak 214 orang dan didapat jumlah sampel sebanyak 59 responden, teknik sampling dalam penelitian ini adalah simple random sampling, uji statistic menggunakan uji chi-square.

Hasil : Hasil uji statistic chi square didapat nilai $P$-Value $<a(0,02<0,05)$ maka HO ditolak. Jadi dapat disimpulkan terdapat hubungan diabetes mellitus pada pasien yang menggunakan insulin dengan kejadian oeteoartritis di RSUD Dr. H. Abdul Moeloek Provinsi Lampung Tahun 2018 dengan Odds Ratio (OR)= 2.037.

Kesimpulan : Saran dapat digunakan sebagai bahan informasi dan masukan dalam meningkatkan pengetahuan pasien dalam menggunakan insulin, yang dapat berdampak pada peningkatan berat badan, dan mempengaruhi fungsi otot dan tulang ekstermitas bawah, sehingga dapat menyebabkan gejala osteoarthritis.

\section{Kata kunci : Diabetes Melitus, Insulin, Osteoarthritis}

\section{PENDAHULUAN}

Diabetes Melitus (DM) adalah gangguan metabolisme yang secara genetik dan klinis termasuk heterogen dengan manifestasi berupa hilangnya toleransi kabohidrat, selain itu diabetes juga diketahui sebagai salah satu penyakit dengan kegagalan memecah glukosa, dikarenakan sedikitnya jumlah insulin yang dikeluarkan (Someita, \& Someita, 2015 ; American Diabetes Association. (1966).

Salah satu komplikasi kronik Diabetes Mellitus (DM) adalah gangguan muskuloskeletal. Penyebab gangguan muskuloskeletal adalah akibat komplikasi mikro dan makroangiopati. Beberapa penyakit rematik yang terkait diabetes yaitu antara lain diabetic shoulder hand syndrome dan limited joint mobilities syndrome, diffuse idhiopathic skeletal hyperostosis (DISH) calcium pyrophosphate dihydrate (CPPD), osteoarthritis, osteopenia, hyperostosis, osteolisis diabetic, sendi neuropatik, frozen shoulder, tenosinovitis, sindroma carpal tunnel dan tendonitis. (Purnomo, 2002); Fatimah, 2015). Salah satu penyakit tulang yang terkait diabetes adalah osteoartritis. Sedikitnya kewaspadaan komplikasi terhadap muskuloskeletal, sehingga gangguan muskuloskeletal pada diabetes seringkali diabaikan (Wahyuningsih, 2009)

Penelitian Putra, Suntoko \& Radityo, 2012. dengan judul "Hubungan Gangguan Muskuloskeletal Pada Pasien Diabetes Melitus Di RSUP Dr. Kariadi Semarang". Didapatkan 54 pasien diabetes dengan gangguan muskuloskeletal 22 (40.74\%) pria dan 32 (59.26\%) wanita. Distribusi umur terbanyak 51 - 60 tahun. Karakteristik variabel dominan meliputi kendali gula darah kategori cukup $23(42.60 \%)$, lama menderita diabetes < 5 tahun (50\%), IMT kategori obesitas 33 (61\%), komplikasi mikrovaskuler retinopati $41 \quad$ (75.9\%), gangguan muskuloskeletal terbanyak 
osteoartris sendi lutut $36(66.7 \%)$. Terdapat hubungan yang bermakna pada derajat osteoartritis sendi lutut dengan IMT $(P=0.026)$.

Sedangkan dalam penelitian yang dilakukan oleh Setiawan pada tahun 2009 mengatakan bahwa dari 128 penderita diabetes melitus tipe II 65 diantaranya mengalami osteoartritis dengan kendali glukosa buruk. Semakin tinggi angka kejadian osteoartritis pada penderita diabetes melitus, akan menurunkan aktivitas dan produktivitas pada pasien tersebut.

Berdasarkan data prasurvey yang dilakukan di RSUD Dr. H. Abdul Moeloek Provinsi Lampung, terhadap 10 responden dengan diabetes mellitus yang menggunakan insulin, didapat 7 responden (70\%) dengan keluhan seperti nyeri sendi, nafsu makan meningkat, obesitas, hingga tekanan darah tinggi, sedangkan 3 responden (30\%) mengatakan jika tidak ada keluhan seperti nyeri sendi dan tulang, melainkan hanya penaikan dan penurunan kadar gula darah dengan cepat.

\section{METODOLOGI PENELITIAN \\ Jenis penelitian ini adalah kuantitatif (non-eksperimen).Jenis penelitian kuantitatif adalah penelitian dengan memperoleh data yang berbentuk angka atau kualitatif yang diangkakan (Notoadmodjo, 2012).}

\section{HASIL PENELITIAN \\ Analisis Univariat}

Tabel. 4.1

Distribusi Frekuensi Karakteristik Responden Berdasarkan Jenis Kelamin Usia Dan Penggunaan Insulin Pada Pasien Diabetes Melitus di RSUD Dr. H. Abdul Moeloek Provinsi Lampung Tahun 2018

\begin{tabular}{ccc}
\hline Jenis Kelamin & $\mathbf{N}$ & Persentase (\%) \\
\hline Pria & 29 & $49.2 \%$ \\
Wanita & 30 & $50.8 \%$ \\
\hline Usia & $\mathbf{N}$ & Persentase (\%) \\
\hline $30-40$ tahun & 15 & $25.42 \%$ \\
$41-50$ tahun & 19 & $32.20 \%$ \\
$51-60$ tahun & 24 & $40.68 \%$ \\
$\geq 60$ tahun & 1 & $1.69 \%$ \\
\hline Total & 59 & $100 \%$
\end{tabular}

Berdasarkan tabel 4.1 di atas maka dapat disimpulkan bahwa pasien DM dengan jenis kelamin terbanyak adalah wanita 30 responden $(50.8 \%)$, dan pria 29 responden $(49.2 \%)$.

Tabel. 4.2

Distribusi Frekuensi Berdasarkan Lama Penggunaan Insulin Pada Pasien Diabetes Melitus di RSUD Dr. H. Abdul Moeloek Provinsi Lampung Tahun 2018

\begin{tabular}{ccc}
\hline $\begin{array}{c}\text { Lama Penggunaan } \\
\text { Insulin }\end{array}$ & Frekuensi & Persentase (\%) \\
\hline$\geq 2$ tahun & 41 & $69.5 \%$ \\
\hline$<2$ tahun & 18 & $30.5 \%$ \\
\hline Total & 59 & $100 \%$ \\
\hline
\end{tabular}

Berdasarkan tabel 4.2 di atas maka dapat disimpulkan bahwa pasien DM yang menggunakan insulin di RSUD Dr. H. Abdul Moeloek Provinsi 
Lampung Tahun 2017 sebanyak 41 orang (69.5\%) yang menggunakan insulin selama $\geq 22$ tahun dan 18 orang (30.5\%) menggunakan insulin selama $<2$ tahun.

Tabel 4.4

4.1.1.3 Distribusi Frekuensi Berdasarkan Gejala Osteoartritis Pada Pasien Diabetes Melitus di RSUD Dr. H. Abdul Moeloek Provinsi Lampung Tahun 2018

\begin{tabular}{ccc}
\hline Kejadian OA & Frekuensi & Persentase (\%) \\
\hline Osteoarthritis & 38 & $64.4 \%$ \\
\hline Tidak OA & 21 & $35.6 \%$ \\
\hline Total & 59 & $100 \%$ \\
\hline
\end{tabular}

Berdasarkan tabel 4.4 di atas maka dapat dapat disimpulkan kejadian OA pada pasien DM lebih banyak 38 orang $(64.4 \%)$ dibandingkan yang tidak mengalami OA 21 orang (35.6\%).

Analisis Bivariat

Tabel. 4.5

Hubungan Diabetes Melitus Pada Pasien Yang Menggunakan Insulin ( $\geq 2$ tahun \& <2tahun) Dengan Kejadian Osteoartritis di RSUD Dr. H. Abdul Moeloek Provinsi Lampung Tahun 2018

\begin{tabular}{|c|c|c|c|c|c|c|c|c|}
\hline \multirow{3}{*}{$\begin{array}{c}\text { Lama } \\
\text { Menggunak } \\
\text { an Insulin }\end{array}$} & \multicolumn{4}{|c|}{ Osteoartritis } & \multirow{2}{*}{\multicolumn{2}{|c|}{ Total }} & \multirow{3}{*}{$\begin{array}{c}\text { P- } \\
\text { Value }\end{array}$} & \multirow[t]{3}{*}{ OR } \\
\hline & \multicolumn{2}{|c|}{ Osteoartritis } & \multicolumn{2}{|c|}{$\begin{array}{c}\text { Tidak } \\
\begin{array}{c}\text { Osteoartri } \\
\text { tis }\end{array} \\
\end{array}$} & & & & \\
\hline & $\mathbf{N}$ & $\%$ & $\mathbf{N}$ & $\%$ & $\mathbf{N}$ & $\%$ & & \\
\hline$\geq 2$ tahun & 27 & 45.8 & 14 & 23.7 & 41 & 69.5 & & 2.037 \\
\hline$<2$ tahun & 12 & 20.3 & 6 & 10.2 & 18 & 30.5 & 0,02 & $(.321$ \\
\hline Total & 39 & 66.1 & 20 & 33.9 & 59 & 100 & & $3.353)$ \\
\hline
\end{tabular}

Berdasarkan tabel 4.5 di atas maka dapat dilihat bahwa dari 59 responden yang menggunakan insulin selama $\geq 2$ tahun sebanyak 41 orang (69.5\%), 27 orang $(45.8 \%)$ dengan

\section{PEMBAHASAN}

\section{Analisis Univariat}

\section{Lama Penggunaan Insulin}

Dari hasil penelitian didapat pasien DM yang menggunakan insulin di RSUD Dr. H. Abdul Moeloek Provinsi Lampung Tahun 2017 sebanyak 41 orang (69.5\%) yang menggunakan insulin selama $\geq$ 2 tahun dan 18 orang (30.5\%) menggunakan insulin selama $<2$ tahun.

Penyakit Diabetes Melitus (DM) merupakan penyakit tidak menular yang mengalami osteartritis dan 14 orang (23.7\%) tidak osteoarthritis. Sebanyak 18 orang (30.5\%) menggunakan insulin selama $<2$ tahun, 12 orang (20.3\%) dengan osteoarthritis dan 6 orang (10.2\%) tidak osteoartritis.

peningkatan terus menerus dari tahun ke tahun. Diabetes adalah penyakit metabolik yang ditandai dengan kadar gula darah yang tinggi (hiperglikemia) yang diakibatkan oleh gangguan sekresi insulin, dan resistensi insulin atau keduanya. Hiperglikemia yang berlangsung lama (kronik) pada Diabetes Melitus akan menyebabkan kerusakan gangguan fungsi, kegagalan berbagai organ, terutama mata, organ, ginjal, saraf, jantung dan pembuluh darah lainnya (Putri, Isfandiari, 2013. 


\begin{abstract}
Otot adalah pengguna glukosa yang paling banyak sehingga resistensi insulin mengakibatkan kegagalan ambilan glukosa oleh otot. Pada awalnya, kondisi resistensi insulin ini dikompensasi oleh peningkatan sekresi insulin oleh sel beta pancreas, selain pada otot resistensi insulin juga terjadi pada jaringan adipose sehingga merangsang proses lipolysis dan meningkatkan asam lemak bebas. Hal inbi juga mengakibatkan gangguan proses pengambilan glukosa oleh sel otot dan mengganggu sekresi sel beta pancreas, fenomena ini disebut lipotoksisitas. Sedangkan otot memerlukan glukosa untuk mengambil sel-sel dalam darah, seperti lemak, protein, maka resiko komplikasi kronik makin meningkat. Demikian juga resiko terhadap komplikasi gangguan muskuloskeletal. Sedikitnya kewaspadaan komplikasi terhadap musculoskeletal (Sugondo, 2009).
\end{abstract}

\section{Kejadian Osteoartritis}

Dari hasil penelitian didapat hasil kejadian OA pada pasien DM lebih banyak 38 orang (64.4\%) dibandingkan yang tidak mengalami OA 21 orang (35.6\%).

$$
\text { Menurut Yaputri (2005) }
$$

Diabetes tipe 2 memiliki tingkat lebih tinggi dari osteoarthritis daripada populasi umum. Osteoarthritis adalah peradangan yang disebabkan struktur sendi robek akibat gangguan metabolik dari waktu ke waktu. Orang-orang yang lebih tua dari 55 tahun memliki obesitas dan diabetes melitus tipe 2 lebih mungkin untuk mengembangkan osteoarthritis, terutama di sendi lutut. Osteoarthritis (OA) adalah bentuk paling umum dari artritis. Ini mungkin disebabkan oleh kelebihan berat badan dikaitkan dengan diabetes tipe 2 . Tidak seperti sendi
Charcot, OA tidak langsung disebabkan oleh diabetes. Sebaliknya, kelebihan berat badan meningkatkan risiko mengembangkan diabetes baik tipe 2 dan OA. Osteoarthritis terjadi ketika bantalan antara sendi (kartilago) robek, menyebabkan tulang untuk menggosok yang memunculkan nyeri sendi pada diabetes. Anda mungkin kesulitan dalam menggerakkan anggota tubuh akibat pembengkakan pada sendi. Pinggul dan lutut adalah daerah yang paling sering terkena OA.

Menurut Peneliti kejadian

OA Salah satu komplikasi kronik Diabetes Mellitus (DM) adalah gangguan muskuloskeletal. Penyebab gangguan muskuloskeletal adalah akibat komplikasi mikro dan makroangiopati. Beberapa penyakit rematik yang terkait diabetes yaitu antara lain diabetic shoulder hand syndrome dan limited joint mobilities syndrome. Komplikasi yang lain diffuse idhiopathic skeletal hyperostosis (DISH) dan calciumpyrophosphate dihydrate (CPPD), osteoarthritis, osteopenia, hyperostosis, osteolisis diabetic, sendi neuropatik, frozen shoulder, tenosinovitis, sindroma carpal tunnel dan tendonitis.

\section{Analisis Bivariat \\ Hubungan Diabetes Melitus Pada Pasien Lama Menggunakan Insulin ( $<2$ Tahun \& $\geq 2$ Tahun) Dengan Kejadian Osteo Artritis di RSUD Dr. H. Abdul Moeloek Provinsi Lampung Tahun 2018}

Hasil analisis menggunakan chi-square, didapat $P$-Value $=0,02$ sehingga $P$-Value $<\mathrm{a} \quad(0,02<0,05)$ maka HO ditolak. Jadi dapat disimpulkan terdapat hubungan diabetes mellitus pada pasien yang menggunakan insulin dengan kejadian oeteoartritis di RSUD Dr. H. Abdul Moeloek Provinsi Lampung 
Tahun 2018 dengan Odds Ratio $(\mathrm{OR})=2.037$ yang berarti peluang responden yang menggunakan insulin $\geq 2$ tahun beresiko mengalami 2.037 kali untuk kejadian $O A$ dibandingkan yang menggunakan insulin $<2$ tahun.

Diabetes Melitus merupakan sebuah penyakit, di mana kondisi kadar glukosa di dalam darah melebihi batas normal. Hal ini disebabkan karena tubuh tidak dapat melepaskan atau menggunakan insulin secara adekuat. Insulin adalah hormon yang dilepaskan oleh pankreas dan merupakan zat utama yang bertanggung jawab untuk mempertahankan kadar gula darah dalam tubuh agar tetap dalam kondisi seimbang. Insulin berfungsi sebagai alat yang membantu gula berpindah ke dalam sel sehingga bisa menghasilkan energi atau disimpan sebagai cadangan energi (Mahdiana, 2010) ; Merentek, 2006. Salah satu komplikasi kronik Diabetes Mellitus (DM) adalah gangguan muskuloskeletal. Penyebab gangguan muskuloskeletal adalah akibat komplikasi mikro dan makroangiopati. Beberapa penyakit rematik yang terkait diabetes yaitu antara lain diabetic shoulder hand syndrome dan limited joint mobilities syndrome. Komplikasi yang lain diffuse idhiopathic skeletal hyperostosis (DISH) dan calcium pyrophosphate dihydrate (CPPD), osteoarthritis, osteopenia, hyperostosis, osteolisis diabetic, sendi neuropatik, frozen shoulder, tenosinovitis, sindroma carpal tunnel dan tendonitis. (Wicaksono, 2011) ; Kurniawan, I. (2010).

Pada penderita diabetes, bila glukosa tidak dimetabolisme dengan baik, maka glukosa akan dimetabolisme melalui enzim aldose reduktase menjadi sorbitol. Sorbitol yang tertumpuk di dalam sel akan menyebabkan kerusakan dan perubahan fungsi sel. Selain itu hiperglikemia menyebabkan glikosilasi protein. Penderita diabetes dengan faktor resiko komplikasi mikroangiopati dan makroangiopati, maka resiko mendapatkan komplikasi kronik makin meningkat. Demikian juga resiko terhadap komplikasi gangguan muskuloskeletal. Sedikitnya kewaspadaan komplikasi terhadap muskuloskeletal, sehingga gangguan muskuloskeletal pada diabetes seringkali diabaikan.

Penelitian ini sejalan dengan penelitian yang dilakukan oleh Putra (2012). Hubungan Gangguan Muskuloskeletal Pada Pasien Diabetes Melitus Di Rsup Dr. Kariadi Semarang dengan $p$-value 0.012 dan $O R$. 2.33 yang artinya ada hubungan Diabetes melitus dengan penggunaan insulin menahun dengan kejadian Osteoartritis di RSUD Bakti Husada Jombang Jawa Timur dengan dan dpat disimpulkan bahwa orang yang menggunakan insulin 2.33 kali lebih beresiko terkenan osteoarthritis. Menurut Osteoarthritis terjadi ketika bantalan antara sendi (kartilago) robek, menyebabkan tulang untuk menggosok yang memunculkan nyeri sendi pada diabetes. Anda mungkin kesulitan dalam menggerakkan anggota tubuh akibat pembengkakan pada sendi. Pinggul dan lutut adalah daerah yang paling sering terkena OA.

$\begin{array}{ccc}\text { Dalam } & \text { penelitian ini } \\ \text { terdapat } 14 & \text { orang yang }\end{array}$ menggunakan insulin $\geq 2$ tahun tetapi tidak osteoarthritis. Hal tersebut bisa terjadi karena menurut teori Purnomo, 2002 ; Indonesia, 2011. Komplikasi Diabetes mellitus yang mengganggu muskuloskeletal tidak hanya penyakit osteoasrtritis tetapi juga bisa terserang Diabetic shoulder hand syndrome dan limited joint 
mobilities syndrome, Diffuse idhiopathic skeletal hyperostosis (dish) calcium pyrophosphate dihydrate (cppd), Osteopenia, Hyperostosis, Osteolisis diabetic, Sendi neuropatik, Frozen shoulder, Tenosinovitis, Sindroma carpal tunnel, Tendonitis.

Pada penelitian ini 14 orang yang menggunakan insulin $\geq 2$ tahun, dan tidak mengalami osteoarthritis berdasarkan jenis kelamin pria sebanyak 5 orang, dengan usia $\geq 45$ tahun sebanyak 2 orang tidak terkena OA, dan usia < 45 tahun sebanyak 3 orang tidak mengalami OA, hasil penelitian ini tidak sejalan dengan teori Maharani, 2007. jika pria berusia kurang dari 45 tahun, akan lebih beresiko mengalami OA dibandingkan usia $\geq 45$ tahun. Sedangkan pada jenis kelamin wanita terdapat 9 orang dengan usia $\geq 45$ tahun yang tidak mengalami OA sebanyak 6 orang, dan usia < 45 tahun sebanyak 3 orang tidak mengalami OA, hasil penelitian ini tidak sejalan dengan teori Maharani. (2007) Wanita berisiko terkena OA dua kali lipat dibanding pria. Walaupun prevalensi OA sebelum usia 45 tahun kurang lebih sama pada pria dan wanita, tetapi di atas 50 tahun prevalensi OA lebih banyak pada wanita, terutama pada sendi lutut. Wanita memiliki lebih banyak sendi yang terlibat dan lebih menunjukkan gejala klinis seperti kekakuan di pagi hari, bengkak pada sendi, dan nyeri di malam hari

Pada penelitian ini 12 orang yang menggunakan insulin < 2 tahun, tetapi terkena osteoarthritis berdasarkan jenis kelamin pria sebanyak 5 orang, dengan usia $\geq 45$ tahun sebanyak 2 orang tidak beresiko terkena OA, dan usia < 45 tahun sebanyak 3 orang dan beresiko mengalami OA, hasil penelitian ini sejalan dengan teori
Yuliasih (2011) jika pria berusia kurang dari 45 tahun, akan lebih beresiko mengalami OA dibandingkan usia $\geq 45$ tahun. Sedangkan pada jenis kelamin wanita terdapat 7 orang dengan usia $\geq 45$ tahun yang mengalami OA sebanyak 5 orang, dan usia < 45 tahun sebanyak 2 orang dan tidak mengalami OA, hasil penelitian ini sejalan dengan teori (Yuliasih, 2011) Wanita berisiko terkena $O A$ dua kali lipat dibanding pria. Walaupun prevalensi OA sebelum usia 45 tahun kurang lebih sama pada pria dan wanita, tetapi di atas 50 tahun prevalensi OA lebih banyak pada wanita, terutama pada sendi lutut. Wanita memiliki lebih banyak sendi yang terlibat dan lebih menunjukkan gejala klinis seperti kekakuan di pagi hari, bengkak pada sendi, obesitas, riwayat trauma lutut, olahraga dan nyeri di malam hari.

\section{KESIMPULAN}

Dari hasil penelitian dengan judul "Hubungan Diabetes Melitus Pada Pasien Yang Menggunakan Insulin Dengan Gejala Osteoarthritis di RSUD Dr. H. Abdul Moeloek Provinsi Lampung Tahun 2018" maka ditarik kesimpulan sebagai berikut.

1. Dapat disimpulkan bahwa pasien DM dengan jenis kelamin terbanyak adalah wanita 29 responden (49.2\%), berdasarkan usia terbanyak adalah 51-60 tahun sebanyak 24 responden (40.68\%)

2. Dapat disimpulkan bahwa pasien DM yang menggunakan insulin di RSUD Dr. H. Abdul Moeloek Provinsi Lampung Tahun 2017 sebanyak 41 orang (69.5\%) yang menggunakan insulin selama $\geq 2$ tahun dan 18 orang (30.5\%) menggunakan insulin selama $<2$ tahun. 
3. Dapat disimpulkan bahwa dari kejadian OA pada pasien DM lebih banyak 38 orang (64.4\%) dibandingkan yang tidak mengalami OA 21 orang (35.6\%)

4. Hasil analisis menggunakan uji chi-square, didapat $P$-Value $<\mathrm{a}$ $(0,02<0,05)$ maka HO ditolak. Jadi dapat disimpulkan terdapat hubungan diabetes mellitus pada pasien yang menggunakan insulin dengan kejadian oeteoartritis di RSUD Dr. H. Abdul Moeloek Provinsi Lampung Tahun 2018 dengan Odds Ratio $(\mathrm{OR})=2.037$ yang berarti peluang responden yang menggunakan insulin $\geq 2$ tahun beresiko mengalami 2.037 kali untuk kejadian OA dibandingkan yang menggunakan insulin $<2$ tahun.

\section{SARAN}

RSUD Dr. H. ABDUL MOELOEK PROVINSI LAMPUNG

Hasil penelitian dapat digunakan sebagai bahan informasi dan masukan dalam meningkatkan pengetahuan pasien dalam menggunakan insulin, yang dapat berdampak pada peningkatan berat badan, dan mempengaruhi fungsi otot dan tulang ekstermitas bawah, sehingga dapat menyebabkan gejala osteoarthritis.

\section{UNIVERSITAS MALAHAYATI}

Diharapkan hasil penelitian ini dapat dijadikan bahan bacaan atau referensi, saat melakukan penelitian, atau sebagai bahan referensi dalam memberikan penyuluhan tentang manfaat dan dampak penggunaan insulin bagi penderita diabetes mellitus.

\section{PENELITI SELANJUTNYA}

Diharapkan bagi peneliti selanjutnya agar dapat menambah variabel penelitian, serta faktor yang tidak diteliti oleh peneliti sebelumnya yaitu ras, genetik, nutrisi, penyakit komorbiditas, dan diharapkan juga hasil penelitian ini dapat dijadikan bahan referensi.

\section{DAFTAR PUSTAKA}

Someita, I. M., \& Someita, I. M. (2015). Pengaruh Active Assistive Range of Motion Terhadap Kadar Gula Darah 2 Jam Postpradial Pada Pasien Dengan Diabetes Melitus Tipe Ii Di Rsud Sanjiwani (Doctoral Dissertation, Universitas Udayana).

American Diabetes Association. (1966). Diabetes (Vol. 15, No. 712). American Diabetes Association.

Purnomo, H. D. (2002). Gangguan Muskulo Skeletal pada Penderita Diabetes Melitus di RSUP Dr. Kariadi Semarang. Program Pendidikan Dokter Spesialis-1 Bagian IMSF IImu Penyakit Dalam. Semarang.

Fatimah, R. N. (2015). Diabetes melitus tipe 2. Jurnal Majority, 4(5).

Wahyuningsih, N. A. S. (2009). Hubungan obesitas dengan osteoartritis lutut pada lansia di Kelurahan Puncangsawit Kecamatan Jebres Surakarta (Doctoral dissertation, Universitas Sebelas Maret).

Yanuarty, M., \& Suntoko, B. (2014). Hubungan Antara Faktor Risiko Osteoartritis Lutut Dengannyeri, Disabilitas, Dan Berat Ringannyaosteoartritis (Doctoral Dissertation, Faculty of Medicine Diponegoro University).

Putra, R. E. N., Suntoko, B., \& Radityo, A. N. (2012). Hubungan Gangguan Muskuloskeletal Pada 
Pasien Diabetes Melitus Di Rsup Dr. Kariadi Semarang (Doctoral Dissertation, Fakultas Kedokteran).

Setiawan, M. (2009). Kelainan Persendian (Osteoartritis) Sebagai Komplikasi Kronis Diabetes Melitus Tipe li Dan Hubunganya Dengan Kendali Glukosa Darah. Saintika Medika, 5(1).

Wahyuni, C. U., Martini, S., Isfandiari, M. A., \& Hargono, A. (2013). Epidemiologi Penyakit Tidak Menular. Surabaya: Fakultas Kesehatan Masyarakat Universitas Airlangga.

Putri, N. H. K., \& Isfandiari, M. A. (2013). Hubungan Empat Pilar Pengendalian DM Tipe 2 dengan Rerata Kadar Gula Darah. Jurnal Berkala Epidemiologi, 1(2), 234243.

Mahdiana, R. (2010). Mencegah Penyakit Kronis Sejak Dini. Yogyakarta: Tora Book.

Merentek, E. (2006). Resistensi Insulin Pada Diabetes Melitus Tipe 2. Cermin Dunia Kedokteran, 150, 38-41.

Wicaksono, R. P. (2011). FaktorFaktor Yang Berhubungan Dengan Kejadian Diabetes
Melitus Tipe 2 (Studi Kasus di Poliklinik Penyakit Dalam Rumah Sakit Dr. Kariadi (Doctoral dissertation, Faculty of Medicine).

Kurniawan, I. (2010). Diabetes melitus tipe 2 pada usia lanjut. Majalah Kedokteran Indonesia, 60(12), 576-584.

Putra, R. E. N., Suntoko, B., \& Radityo, A. N. (2012). Hubungan Gangguan Muskuloskeletal Pada Pasien Diabetes Melitus Di Rsup Dr. Kariadi Semarang (Doctoral Dissertation,

Fakultas Kedokteran).

Purnomo, H. D. (2002). Gangguan Muskulo Skeletal pada Penderita Diabetes Melitus di RSUP Dr. Kariadi Semarang. Program Pendidikan Dokter Spesialis-1 Bagian IMSF IImu Penyakit Dalam. Semarang.

Indonesia, P. E. (2011). pengelolaan dan pencegahan diabetes melitus tipe 2 di Indonesia. dalam Konsensus.

Maharani, E. P. (2007). FaktorFaktor Risiko Osteoartritis Lutut (Studi Kasus di Rumah Sakit Dokter Kariadi Semarang) (Doctoral dissertation, program Pascasarjana Universitas Diponegoro). 